\title{
TRANSFORMING FOOD SUPPLY SYSTEMS BY RE-EVALUATING THE PRODUCT OFFERINGS OF SMALL FARMERS
}

DOI: http://dx.doi.org/10.18509/GBP.2020.50

UDC: $338.439 .5: 339.188 .2]: 631.115(498-18)$

\author{
Matei Daniela ${ }^{1}$ \\ Chiriță Viorel ${ }^{2}$ \\ ${ }^{1}$ Social and Economic Institute "Gh. Zane", Iași Branch, România \\ 2 "Ștefan cel Mare" University of Suceava, Suceava, România
}

\begin{abstract}
According to tradition, in Romania, a significant percentage of food products of animal and non-animal origin, which provide the consumer market, are produced and marketed by small agricultural producers (private persons or legal entities) that have the purpose of animal husbandry or agriculture crops. These activities are, most often, supported by the county and local authorities by providing the institutional and legal framework, by organizing and modernizing the existing agro-food markets, organizing fairs and traditional events or by granting financial resources such as subsidies, prizes or other subsidized taxes. The presence of the agro-food markets and the fairs or livestock markets as well as their distribution is an important indicator of the level of development of the local economic activities (agricultural and non-agricultural) in the Romanian rural area. The issue performs an assessment of the distribution of the agro-food markets in the Botoșani county, which has the agriculture as a predominant activity, in order to succeed an overview of the degree of valorizations, of the production obtained by the farmers and destined for commercialization.
\end{abstract}

Keywords: agri-food, subsistence, peasant markets, small farmers, accessibility

\section{INTRODUCTION}

The present-day economic literature underlines the global trend of diminishing the value of peasant agriculture. The countryside spaces are mentioned in the context of rural depopulation [1], [2], of home and foreign migration [3], [4], [5] or of the difficulties of living and working conditions [6], [7].

The current approaches of the market economy regard the peasant household as an underveloped way of life which should be rooted out in the 21st century [8]. However, as long as the worldwide conditions, which support its mechanisms, are changing (by facing challenges such as food supply difficulties, climate change, natural disasters or steering towards local products, etc.), the survival models are being reinterpreted.

Under such a scenario, the importance of peasant economy is re-assessed due to its selfsupporting capacity that relies merely partially on the market and commerce [9], [10].

On a global scale, food sovereignty and security are equally turning into issues of both less developed and highly developed countries. The increasing dependency on the global market and its mechanisms of inflationary pressure and speculative nature [11] have determined FAO to replace the term of food security with that of food sovereignty in what concerns public documents (since 2012).

The reason behind such an action relies on the fact that "food sovereignty is a necessary prerequisite for attaining genuine food security". Under the circumstances, views upon 
the future of the peasant agriculture are varying: some authors share the certainty that "peasants will no longer exist in the world of capitalist globalization" [12], while others regard the peasant household and agriculture as an appropriate model for a food and environmental future portrayed through sustainability and progress [13].

Having as a starting point the assumption that food sovereignty means the right of peoples to consume what they produce; the present paper performs an analysis on the usage of native food products by the Romanian consumers. The interface employed for research purposes is the peasant market of agro-food products which are produced, processed, and sold in a limited space and time range.

\section{AGRIFOOD MARKETS AND RECALIBRATION OF PEASANT HOUSEHOLD}

In Romania, the agrarian economy has a significant weight as almost a quarter of the country's population, more precisely $23 \%$, is currently engaged into agricultural activities, while the EU average reaches merely $4 \%$ [14]. The percentage is supported by the fact that over half the country's population still lives in the rural area and, approximately $85 \%$ of the total labor force engaged in agriculture is self-employed, working in their own subsistence farms [15]. Although the above data is mostly regarded as a highlighter of the issues Romania is facing in its attempt to better integrate within the community market, the authors provide a different perspective. This view concerns the sustainability granted by the Romanian peasant economy and its value within the European agricultural policy.

Although the past 30 years have been marked by relatively constant efforts for broadening the rural economy and increasing the ponderosity of non-agricultural activities (agro-food processing, services, and tourism), the present analysis focuses on the key role still played by the peasant economy in the Romanian agro-food system, fortunately, as we would like to add. Thus, the strength and endurance of the peasant economy becomes visible through two main features that are different and measurable at the same time, namely: the selfconsumption level and large number of agro-food markets in the rural area.

In the Romanian agricultural sector, there are roughly 3,4 million farms and over $85 \%$ of them have a self-consumption that exceeds $50 \%$ of the annual production (known as subsistence and semi-subsistence farms) [16]. The high volume of self-consumption recorded and regarded as a barrier in rural development, has worked for 30 years as a safety net for those classes of population that were mostly affected by the economic changes. Therefore, at least a part of the peasant economics has proven its resilience to a developing rural economy oriented towards market and managed to keep its autarchic features.

It is against this background that farmers 'markets have partially taken over the production of peasant households (especially small and medium-sized farms) and provided a food supply alternative which accomplishes a vital premise, namely: employment of native food and non-food products to a degree that exceeds any other type of market. In terms of agricultural policy, the Romanian farmers 'markets embody a class of food security supported by food sovereignty which responds to a cycle of supply and demand, and where food is primarily a right, and secondly a business. A closer look at the evolution of farmers "markets in the latest years has been also supported by the emergence of an increasing market segment, namely consumers of local products. Further, these products fit into a trend that is making a strong comeback to self- 
consumption worldwide, as an expression of the self-protection desire/ need to the food risk and risk of suppliers 'dependency as well [17], [18].

In the case of the present paper, Botoșani county, located in the North-East of Romania, has been selected due to the agrarian predominance of its economy (Fig. 1).

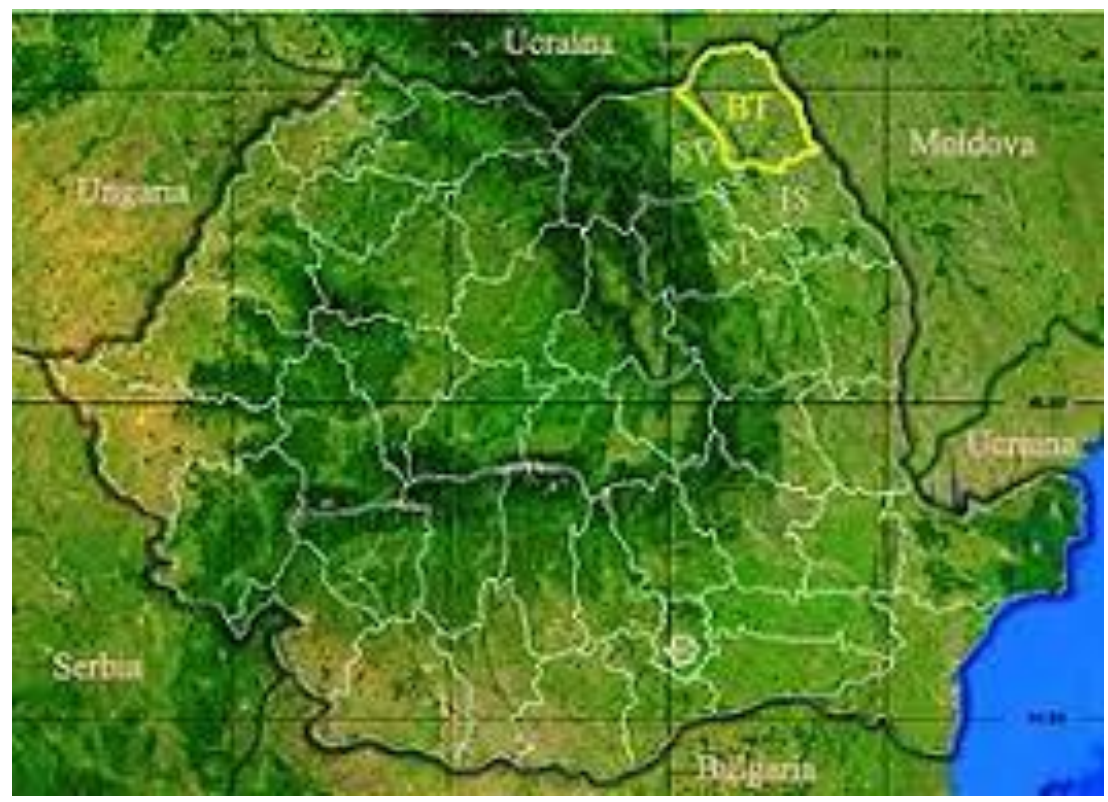

Figure 1. The Botoşani County - in the North -East of Romania

It closely related to the presence of large and very large farms mainly specialized in producing straw cereals and oil plants, but it also concerns many small and very small farms. This latter class of farms generally grows maize which feeds both animals and humans, as well as various other plants included in the human diet, such as beans, potatoes, tomatoes, greens and fruit. In addition, most small farms raise 1-2 dairy cows, poultry, a few sheep or goats, 1-2 pigs which cover most of the food necessities of a family that manages a small peasant household. These products no longer cross the market but take the form of self-consumption and the so-called "short supply chains". According to the Survey of Family Budgets [15], in the Romanian rural households, approximately $66 \%$ of the total expenses on food is represented by the consumption value from their own resources.

For most people living in Botoșani county, agriculture is a way of life. As regards the figure of 110.351 agricultural holdings without legal personality that manage, on average, $2,15 \mathrm{ha} /$ holding, the question of selling their agricultural surplus happens occasionally or it concerns another segment, namely $0,04 \%$ (44 holdings) that is organized as authorized physical person, individual entrepreneurship or family entrepreneurship (which generally manages $90 \mathrm{ha} /$ holdings). Related to market participation, the agricultural households can sell between 0 and $100 \%$ of their production on a constant basis or depending on production and decision taken by the holding manager. At opposite extremes, there are the subsistence holdings and commercial holdings, and in between, various combinations which tilt the economy to improving a way of life or towards profit and structural diversification. 


\section{WAYS OF COMMERCIALIZING THE AGRICULTURAL PRODUCTS OBTAINED IN SMALL AND MEDIUM-SIZE FARMS}

1. The direct sale to markets and fairs is the most employed practice by small producers who sell their products. This variant is generally favored by farmers who practice a subsistence agriculture and have small amounts of products for sale. Given that they have limited amounts of products they do not have to stay too much in a market or move over long distances to sell the production which is not meant for selfconsumption. Further, by employing this way of commercializing, they can sell at relatively higher prices than they would normally do it in the wholesale system, which means a higher profitability rate. Concerning the necessary documents for running a legal operation of this sort, a producer certificate at this level is quite enough. The small agricultural producers can sell in markets based on their producer certificate, while the occasional commerce of agricultural products is exempted from the obligation of having fiscal cash registers. Additionally, they can commercialize their products in markets, fairs, and even shops/ stores/ supermarkets provided that they have a private limited company or run their economic activity as authorized physical person, individual, or family enterprise.

2. The direct sale to the client's door is a practice frequently adopted in the case of dairy products and traditional or bio products sold to the subscribed customers. It is a method which allows a certain type of certitude in selling products and shows the farmers 'concern for some inceptive features of marketing and sales forecast.

3. A situation which is more and more common inside cities relies on the practice of agri-food orders with delivery at a fixed location. In time, farmers have developed a network of clients who are often young people highly educated in terms of food education and generally have an above-medium income. Thus, freshly harvested or processed products (such as vegetables, fruit, egg, bread, etc.) are preferred by these clients. The farmer usually keeps in touch online with his/ her clients, specifies the type of available product and quantities and establishes 3-4 delivery points in town/ city within a previously arranged timetable. The orders are placed online or by phone and the clients go to the pick-up points to take their basket of products ordered. This sales method creates a direct bond between farmers and consumers. Additionally, most clients go to the farms, at least once, to see with their own eyes the conditions of production, harvesting, and storage. From a different perspective, the feedback provided by consumers on the farmer's website turns into an efficient and cheap promotion tool or, on the contrary, can make an instant correction with real-time repercussions.

4. The sales to intermediate dealers constitute a method that sometimes is employed by the small farmers managing farms that are slightly bigger than usually and who have crossed the threshold of subsistence agriculture. They can commercialize larger quantities of products and sell them to companies or dealers that will eventually sell them to certain retailers. This aspect concerns the authorized middle persons (companies which have access to wholesale storage units and /or wholesale markets) and unauthorized middle persons (persons who work off the grid and purchase wholesale agro-food products to resell them to the so-called "market mob"); in this latter case, it is necessary to provide providence documents of the products acquired, except for the sales to companies which have as activity object the grain commerce (in these cases, a sales note is enough). 
5. The sales that use small shops/ stores. It usually involves delivering products directly to certain shops/ stores which commercialize retail food products, mainly grocery stores or convenience stores.

6. The sales to hypermarkets/ supermarkets /convenience stores. This approach provides the possibility of valorizing the native agricultural products, partially due to the pressure exerted by the Romanian Ministry of Agriculture and Rural Development to have higher percentages of native products supplied by short food supply chains in all the major shops/ supermarkets. Even if the hypermarkets have higher demands (special conditions of quality and quantity) and few of the small farmers can meet these conditions, it is still a step ahead in the long-term process of valorizing the local agricultural production.

7. The biggest profits are obtained by the small producers/ farmers who produce bio products and sell them directly for export. These entrepreneurs must have a company for producing and commercializing their products (under Law no. 31/1990 or Government Emergency Ordinance 44/2008) and satisfy a series of specific requirements as well.

\section{VALORIZATION OF AGRICULTURAL PRODUCTS OBTAINED IN SMALL AND MEDIUM FARMS IN FARMERS' MARKETS, FAIRS, AND STOCKYARDS}

The presence of farmers 'markets, fairs and stockyards, as well as their distribution across the area analyzed are key indicators for the development level of the economic activities (agricultural and non-agricultural) run in the Romanian rural space. The present paper aims at making their distribution assessment and, thus, obtain an overview of the valorization degree and production intended for commercializing as well.

The data collected from Botoșani County Council [19] has been used here for documentation purposes, more precisely, historical references [20]. The analysis intends to separate, where data allows it, the situation of fairs and stockyards from that of markets and bazaars that are joined or assimilated by the neighboring or host markets in the rural areas.

In 2019, there were 37 farmers 'markets in Botoșani county, 49 fairs organized on various events (such as city's/ village's day, religious celebrations), and 10 stockyards. Given that the county in question has a high rural ponderosity, we have also considered the markets, fairs, and stockyards in this assessment. The outcome of this process has been synthesized in Figure 2, to get a complete picture of the coverage rate. Thus, the municipalities of Botoșani and Dorohoi, as well as those of Săveni, Darabani and Flămânzi towns, have daily farmers 'markets where activities are run and managed in an institutionalized system, in spaces built and adjusted to the particular structural features of the markets, and usually located in the center of cities/ towns. This last aspect reveals the role played by the agricultural activities in the development of the urban areas in Botoșani county. The markets are more than polarizing areas, they are emerging urban areas for commercial agricultural activities.

For instance, Botoșani municipality has 3 daily farmers 'markets which attracts producers from all over the county and neighbouring counties as well, and constant customers who have developed stable relations with the producers and order quantities of various products which can secure a family's livelihood (in term of food necessities) for a whole season or year sometimes. There are quite common the cases when buyers from Suceava 
or Iași counties order as early as winter the pickled vegetables, pork or mutton products, goat or sheep cheese preserved in wooden barrels for the next cold season.

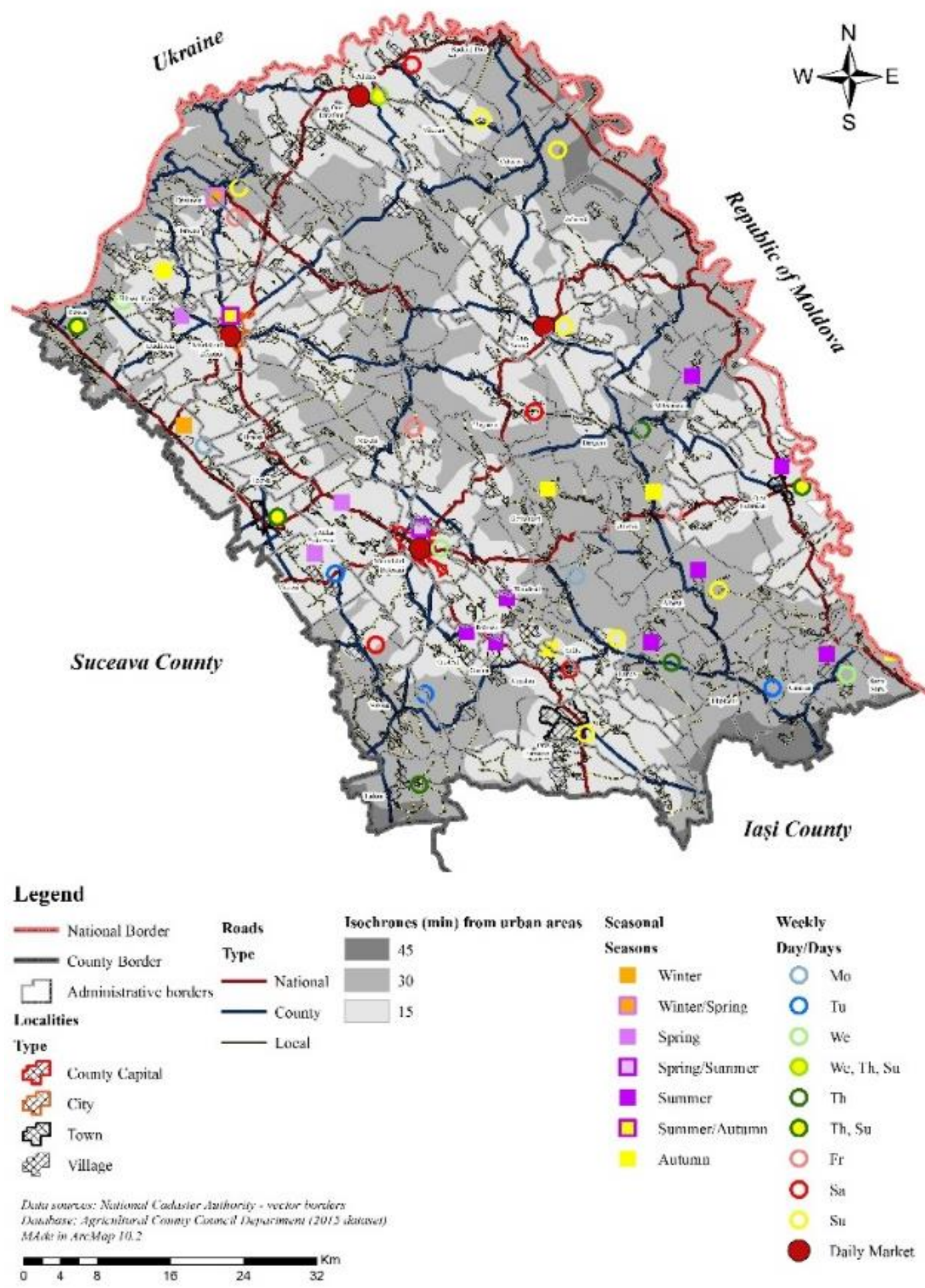

Figure 2. The agri-food markets distribution and typology in the territory of Botoșani county

The reachable location of Botoșani municipality also encourages the supply of products over a wide area (within the isochrone of 15-30 minutes), ranging as far as villages: 
Leorda up north, Nicșeni to the north-east, Bălușeni to the south-east, Vlădeni to the west and Unţeni to the north-east.

Besides the daily market, in Darabani there are also 3 fairs every week (on Wednesday, Thursday, and Sunday). This commercial dynamism is related to the wide variety and abundance of agricultural products and perhaps, more closely to a long-standing tradition favoured by the high-density of transportation means that have allowed collecting products from the northern part of the county to Rădăuți Prut, from the southern side to Mileanca/ Havârna, from the south-west part to beyond the borders of Hudești and from the south-east to Coțușca.

To the east, within a perimeter comprising many rural settlements in remote areas, the daily fairs from Săveni town are completed by the Sunday fair. In many respects, they are the result of the polarizing role played by this town within a very wide range with an isochrone of 15-45 minutes, along DN 29, DJ 282, and DJ 292 national roads.

The weekly farmers' markets have different locations across the county. Those organized at weekends are more common and have primarily developed in the polarizing rural areas and secondly in the urban areas where, markets are generally week-long open. The polarizing rural centers confirm, through the distribution of agro-food markets, the role played by the transport networks in the local economic development, namely: Sulița Dracșani, Corni (located across a market open on Saturdays in Verești - Suceava, on the other bank of Siret river), Ungureni (located on Todireni-Dorohoi railway which crosses the county from north to south), Nicșeni, Roma, Sulița.

There are also worth mentioning the markets organized on Sundays in the following towns: Bucecea, Săveni, Ștefănești and Flămânzi, along with the local agri-food markets which are organized on a regular basis in almost half of the commune seats.

On the northern and north-east border of the county, within the areas of economic importance in terms of grain production, there are organized markets in centers located on road junctions, such as: Viișoara and Coțușca, Darabani and Cristinești or Dersca. Within this intersection points, certain areas of local rural polarization are created for particular types of products (mainly dairy products and grains) or polarize remote areas from the deep rural of the county (Rădăuți Prut, Mitoc, Coțușca or Cristinești - up north, or Albești down south). The status of polarizing rural areas is also confirmed by the two fairs organized weekly, usually on Saturdays and Sundays in Bucecea and Ștefănești towns or in Dersca village.

Another category of agricultural markets includes the seasonally or temporarily functioning ones. Among these, most markets which are effective during springtime arise in the southern part of the county on the south-west border and southern one as well. The seasonal fairs are primarily associated with a local religious celebration, often the feast day of a local patron saint. Besides their obvious economic part, these markets also reaffirm the preservation of the old agricultural and bartering commercial relations which are territorially rooted as social and calendar hallmarks within a quasi-homogenous geographical space.

The spring fairs are related to activities such as the purchase of seeds, seedlings, fruit trees, young farm animals, while the autumn ones are connected to the dissolution of sheepfolds, commercialization of grains for the cold season, and supplying vegetables for pickling and preservation. At last, the winter fairs usually sell animal products, especially pork products. These fairs are generally grouped in the peri-urban localities of Botoșani city (Bălușeni, Blândești, Coșula), and other towns (Ștefănești) located in south-west part of the county. Up north there is a market situated in Pădureni close to Dorohoi town. 
The towns have markets specific to late spring and early summer (Botoșani) or early autumn (Dorohoi), becoming polarization cores of the county's commercial agricultural activities. These markets have developed this activity for both seasonal products (early vegetables and fruit brought from the peri-urban areas) and animal products (mostly dairy and meat products) supplied by the small producers or clusters of farmers. In wintertime there are fewer fairs. One of the most important ones is located in Vârfu Câmpului at the border with Suceava county and it facilitates the traditional marketing of the products made in the Moldavian Plain (grains, cattle, sheep) and Suceava Plateau, especially the region of Zvoriștea - Adâncata (potatoes). The other fairs are organized in Gorbănești and Trușești communes.

Another major method of valorization (typical of the livestock) is represented by the stockyards. The biggest ones are organized in the following localities: Trușești, Ștefănești, Săveni, Darabani, Dorohoi and Botoșani. At municipality level, the local public authorities and agricultural directorates remain largely unaware of the stockyards 'role, their importance/ necessity for the local market and valorization of small producers 'products and, consequently, they are far from being appropriately organized. In what concerns the stockyards organized in the rural areas, they generally lack watering troughs, pastures, sometimes enclosures or proper fences and a proper division of animals which are often mixed together. This situation draws a series of difficulties, such as the proper assessment of the animals 'breed or number. Other stockyards are organized in the localities of Flămânzi, Călărași, Răuseni, Copălău - Sulița, Roma-Răchiți, although they are smaller and market fewer animals.

\section{CONCLUSIONS}

Based on the analysis run on the valorization potential of the agro-foods products in the rural communities of Botoșani county through local markets, the following general conclusion have been reached:

- The county's urban development mostly relies on the vitality of the rural spaces located nearby.

- Small towns play a transitory part making the shift from the subsistence agriculture to one focused on market, processing industry, and services provided to farmers.

- The poor infrastructure interferes with both market access of the native products and potential investors interested in agriculture, as they tend to focus around urban centers and along the main roads and railway corridors which are "genuine development corridors". We are dealing with a space that is well-developed and economically active in the western part of the county, especially in Botoșani and Dorohoi - two polarizing centers which will most likely fusion at a given time - and a town/ fair (Săveni) located in the central-east area, which polarizes the deep rural within a quasicircular radius. Regarding the rest of the county's territory, the wholesalers of vegetables, fruit, dairy products and other agro-food products choose to bring their goods from abroad, instead of collecting these products from local farmers due to the higher costs for collecting and transportation of the goods and long delivery times as well. The latter aspect is largely due to the poor quality of roads and the particular nature of deep rural areas located in the eastern, northern, and southern borders of the county. These regions have three peripheral centers of low polarization (again, the fragile infrastructure takes all the blame here), namely Darabani, Flămânzi and Ștefănești. In conclusion, if there were a proper, functional and updated transport 
infrastructure, the entire area of Botoșani county could become a dynamic economic region.

- It is necessary to pay more attention to the relations and networks which operate among different functional groups within the county's agricultural system, as they will be able, in time, to manage the existing spatial and sectorial bonds and lead to the development of new poles of rural growth.

- Focusing the valorization of agro-food products in daily open farmers 'markets and fairs could provide a new dimension to the rurban effectiveness of the small and medium towns in the process of necessary alignment of the peri-urban area to the supply factors of the agricultural spaces.

- Fairs, stockyards, and fairgrounds (e. g. Darabani, Trușești, Ștefănești) could become economic and tourist polarizing centers with impact upon the development strategy of the deep rural areas (with emphasis on agro-tourism and shopping tourism).

- The analysis run in these pages has led us to another key conclusion: market is a social construct. If we have in view the number of 110.351 agricultural holdings without legal personality in the county, the market is not just the place where various products are sold and get to diversify the daily basket of a large number of the rural population, but it is also the place where the association is initiated and consolidated to increase production and diversify the farms' incomes. The emergence and maintenance of markets in certain areas are clear indicators for the dynamics of the political and local context, which trigger certain institutional types of market created to satisfy the financial interests of the main players involved, even if this institution is not always the best choice.

- The pressure applied on the county's farmers by the limited presence of other development resources along with the geographical isolation of the county has led to the necessity of association. Even if not all 216 forms of association registered in 2018 with the Agricultural Chamber of Botoșani county are fully operational, the fact that they are present across the entire county and in all communes shows that this necessity has been well- acknowledged at a certain point. Now only time and development resources of each commune or association group will tell when they turn into key players on the market. Beyond the experience of forced cooperativization during the Communist Regime which ended not so far ago (30 years ago), the cooperatives/ association/ groups of producers represent an important pillar of rural development through the activities run and make a significant contribution to the optimization of agricultural activity both in the upstream (by effectively providing the production resources) and in the downstream direction (by getting a more favorable position when negotiating with different traders from the product distribution chain).

- At the end, considering the picture provided by the analysis of a predominantly agricultural space, the following question arises most naturally: Is the Romanian rural space prepared for the development dynamics of the more developed Western countries? The political and entrepreneurial environment constantly hope for a future of the Romanian village when agriculture plays a smaller part than it does today. A large portion of the rural space will be marked by new functionalities: non-agricultural activities, but cultural, tourist or residential activities in the villages located nearby towns/ cities. Around the big cities of Romania this phenomenon is quite visible: agricultural spaces invaded by localities for building industrial facilities, micro industry activities, and IT businesses. An urban society, that becomes more and more confined to make optimum use of the built-up areas, will concentrate enough 
resources of information and communication to achieve the transfer of its own production units to the rural environment. This will seriously affect the agricultural role of the village, agricultural domain, and rural space overall, but mostly it will have an impact on the supply systems of the nearby urban markets in terms of fresh agrofood and immediate necessity products.

\section{REFERENCES}

[1] Kohler, T., Elizbarashvili, N., Meladze, G., Svanadze, D., Meessen, H., The Demogeographic Crisis in Racha, Georgia: Depopulation in the Central Caucasus Mountains, Mountain Research and Development, 37(4), 217), pp 415-424, DOI: 10.1659/MRD-JOURNAL-D-17-00064.1

[2] Zotic, V., Alexandru, D.E., Iacobiniuc, L.M., The loss of villages in România after 1990, Studia Universitatis Babes-Bolyai, Geographia, 61(2), 2016, Romania, pp 101-136

[3] Bogdanov, G. and Rangelova, R., Social Impact of Emigration and Rural-Urban Migration in Central and Eastern Europe, Final Country Report Bulgaria, 2012, pp 120

[4] Jemna, D., Pintilescu, C., \& Turturean, C., Population in Romania within the united Europe. Analele Stiintifice ale Universitatii "Alexandru Ioan Cuza" din Iasi-Stiinte Economice, Romania, 2010, pp 329-340.

[5] Dax, T., \& Fischer, M., An alternative policy approach to rural development in regions facing population decline. European Planning Studies, 26(2), 2018, pp 297-315.

[6] Zhang, Y., Chen, M., \& Shi, X. Q., Challenges of basic public health services provided by village doctors in Guizhou, China. Asia Pacific Journal of Public Health, 27(2_suppl), 2015, pp 69S-76S

[7] Alpaslan, N. \& Schenck, R., Challenges related to working conditions experienced by social workers practising in rural areas. Social Work/Maatskaplike Werk, 48(4), 2012

[8] Collantes, F., Pinilla, V., Sáez, L. A. and Silvestre, J., Reducing Depopulation in Rural Spain: The Impact of Immigration, Popul. Space Place. 20, 2014, pp 606-621.

[9] Van der Ploeg, J.D., The new peasantries: rural development in times of globalisation, Routlege, England, 2018, pp 24-28

[10] D'Orfeuil, H.R., Transition agricole et alimentaire. La revanche des territoires, ECLM, Paris, 2018, pp 45-50

[11] Belletti, M., The emerging role of the peasant economy at the end of the industrial age: insights from Albania. Procedia Economics and Finance, 33, 2015, pp 78-89.

[12] Bernstein, H., Food Sovereignty via the "Peasant Way": a Sceptical View, Journal of Peasant Studies, 41 (6), 2014, pp 1031-63.

[13] Marsden, T., \& Farioli, F., Natural powers: from the bio-economy to the eco-economy and sustainable place-making. Sustainability Science, 10(2), 2015, pp 331-344.

[14] EUROSTAT, 2018

[15] National Institute of Statistics, Romania, 2018

[16] Productivity of the Romanian agricultural sector. A structured approach, Monthly bulletin, The National Bank of Romania, 2018

[17] Toffler, A. \& Toffler, H. The Revolutionary Wealth, Ed. Currency/ Doubleday, New York, 2006, pp 110-112

[18] Dusi, D., Beyond prosumer capitalism: Retaining the original understanding of prosumption. Current Sociology, 66(5), 2018, pp 663-681

[19] Calendar of markets, fairs and festivals, Botoșani County Council, 2019

[20] Prăjinariu,I.V., Târgurile din județul Botoșani. Studiu de geografie istorică, (The fairs in Botoșani County. Study of historical geography), Ed. Quadrat, Botoșani, România, 2004, pp 3538 